\title{
Is the process of $\beta$-cell destruction in type 1 diabetes at time of diagnosis more extensive in females than in males?
}

\author{
Paolo Pozzilli ${ }^{1,4}$, Chiara A Mesturino ${ }^{2}$, A Crinò ${ }^{3}$, Todd M Gross ${ }^{5}$, Lily M Jeng ${ }^{5}$ and Natalia Visalli ${ }^{1}$ for the \\ IMDIAB Group \\ ${ }^{1}$ University of Rome Campus Biomedico, ${ }^{2}$ University of Rome 'La Sapienza', ${ }^{3}$ Ospedale Pediatrico Bambin Gesù, Rome, Italy, ${ }^{4}$ Department of Diabetes and \\ Metabolism, St Bartholomew's Hospital, London, UK and ${ }^{5}$ Minimed Inc., CA, USA \\ (Correspondence should be addressed to P Pozzilli, Department of Diabetes and Metabolism, St Bartholomew's Hospital, St Bartholomew's Close, London \\ EC1A 7BE, UK; Email: p.p.pozzilli@mds.qmw.ac.uk)
}

\begin{abstract}
Objective: To evaluate sex differences in patients with insulin-dependent diabetes mellitus (type 1 diabetes) by comparing the integrated parameters of metabolic control at the time of clinical diagnosis and 3 months after intensive insulin therapy in pre-pubertal, pubertal and post-pubertal patients. Design: A total of 331 consecutive patients with newly diagnosed type 1 diabetes were studied. The mean age of the group was 15 years (S.D. 8.1; range 5-23 years). Patients were stratified into three groups according to their age at disease onset: pre-pubertal (ages 5-9 years), pubertal (ages 10-18 years) and post-pubertal (ages 19-23 years).

Methods: Glycated haemoglobin $\left(\mathrm{HbA}_{1 \mathrm{c}}\right)$, insulin dose and both basal and glucagon-stimulated C-peptide were evaluated at diagnosis and after 3 months of insulin therapy.

Results: We found that females diagnosed after puberty were those with the lowest basal C-peptide compared with males $(P=0.005)$. No statistically significant differences were observed for other metabolic parameters. When the entire group was evaluated, females at the time of diagnosis showed significant lower body mass index $(P=0.001)$, lower basal $C$-peptide $(P=0.021)$ and higher $\mathrm{HbA}_{1 \mathrm{c}}(P=0.023)$ and required more insulin than males $(P<0.001)$. After 3 months of therapy, only a significantly greater dose of insulin was observed in females compared with males $(P=0.001)$, with similar good metabolic control as assessed by $\mathrm{HbA}_{1 \mathrm{c}}$.

Conclusions: We conclude that the process of $\beta$-cell destruction at diagnosis may be more extensive in post-pubertal females than in males. Moreover, after the introduction of insulin therapy, females and males show similar metabolic parameters, although females still require significantly more insulin than males to achieve good metabolic control, 3 months after diagnosis.
\end{abstract}

European Journal of Endocrinology 145 757-761

\section{Introduction}

Insulin-dependent diabetes mellitus (type 1 diabetes) results from the destruction of $\beta$ cells as a consequence of an autoimmune process in the pancreas (1). The disease can occur in individuals of any age, but it is more frequent in pre-pubertal individuals and in adolescents (2). Differences in clinical characteristics at diagnosis have been described for those patients who were diagnosed at a very young age ( $<9$ years) compared with adult patients and in pre-pubertal, pubertal and postpubertal ages (3).

Sex differences in disease incidence have also been noted previously, with a slight preponderance of males over females in geographical regions of high incidence of type 1 diabetes, such as northern Europe and Sardinia (4), but no similar differences were reported for areas of low incidence (5). The role of sex in the clinical presentation of the disease has not been fully explored.
The present report evaluates sex-based differences in metabolic parameters of patients with recent-onset type 1 diabetes in a population-based study carried out in Rome and its province since 1989. The network includes registration of new cases (Eurodiab ACE) (ages $0-15$ years) and participation in clinical trials (IMDIAB) (ages 5-35 years) aimed at protecting residual $\beta$-cell function $(6,7)$. Previous reports have focused on agebased differences in clinical presentation of type 1 diabetes $(2,8,9)$, but data on sex-based effects on residual $\beta$-cell function and clinical presentation have not been reported. Such an evaluation may afford a better understanding of the disease process leading to type 1 diabetes.

\section{Participants and methods}

A total of 331 patients was available for analysis. Patients included those acting as controls in the clinical 
trials of the IMDIAB group and those who did not take part in such studies. All patients were consecutively diagnosed cases of type 1 diabetes registered in the Lazio region over the previous 10 years. Lazio is considered to be a region of low incidence of type 1 diabetes ( 8 in $100000<15$ years of age) and no significant sexrelated difference in disease incidence has been found over a period of 10 years of observation (10).

At disease presentation, in addition to the collection of demographic data, a venous blood sample was taken for routine analysis including measurement of glycated haemoglobin $A_{1 c}\left(H_{b} A_{1 c}\right)$. Metabolic results were obtained in local laboratories and no attempt was made to normalize results obtained from different locations.

Baseline and stimulated (1 mg i.v. glucagon) C-peptide secretion were evaluated soon after blood glucose concentrations had been normalized (usually within 1 week of diagnosis). The stimulated test was performed under fasting conditions in the morning, after blood glucose values had been checked and confirmed as $<10 \mathrm{mmol} / \mathrm{l}$, which was the limit set for the test to be carried out. C-peptide was measured by radioimmunoassay, using a commercially available kit (BioRad). The normal range of fasting C-peptide established in 150 control individuals ( 71 females and 79 males aged 540 years, median 18 years) with no family history of type 1 diabetes was $1.1-2.9 \mathrm{ng} / \mathrm{ml}$, with intra- and interassay coefficients of variation ranging from 10 to $14 \%$.

Insulin therapy (three or four injections daily) was started as soon as possible after diagnosis to achieve normal metabolic control according to the same standard procedure used in our region since 1989 (6) and in view of the demonstration that intensive insulin therapy may prolong the remission phase (11). The dose of insulin required to optimize metabolic control was monitored monthly up to 3 months after diagnosis. At that time, the glucagon test was repeated, as above. $\mathrm{HbA}_{1 \mathrm{c}}$ was also measured.

Means \pm S.D. were used to describe numerical variables. Differences between males and females with respect to demographic and metabolic variables were tested using independent-sample $t$-tests. Differences in the distribution of males and females across age and puberty categories were tested using $\chi^{2}$ analysis. Changes in the disease parameters over time were assessed with paired $t$-tests. All statistically significant findings for body mass index and C-peptide were adjusted for age as a covariate and confirmed with analysis of covariance.

\section{Results}

Table 1 presents a comparison of males and females with respect to demographic and metabolic variables. Females were significantly younger $(P=0.014)$ and 
Table 2 Comparison of male and female pre-pubertal patients at the time of diagnosis and after 3 months of insulin therapy.

\begin{tabular}{lcccc}
\hline & \multicolumn{2}{c}{ Diagnosis } & & \\
\cline { 3 - 5 } Sex & No. & $\begin{array}{c}\text { Basal C-peptide } \\
(\mathrm{ng} / \mathrm{ml})\end{array}$ & $\begin{array}{c}\text { Stimulated C-peptide } \\
(\mathrm{ng} / \mathrm{ml})\end{array}$ & $\begin{array}{c}\text { Basal C-peptide } \\
(\mathrm{ng} / \mathrm{ml})\end{array}$ \\
\hline Female & 36 & $0.4 \pm 0.4$ & $1.0 \pm 1.0$ & $\begin{array}{c}\text { Stimulated C-peptide } \\
(\mathrm{ng} / \mathrm{ml})\end{array}$ \\
Male & 43 & $0.6 \pm 0.5$ & $1.4 \pm 1.3$ & $0.7 \pm 0.6$ \\
\hline
\end{tabular}

Values are means \pm S.D. Values for females and males are not statistically different.

Table 3 Comparison of male and female pubertal patients at the time of diagnosis and after 3 months of insulin therapy.

\begin{tabular}{lcccc} 
& \multicolumn{2}{c}{ Diagnosis } & & \\
\cline { 3 - 5 } Sex & No. & $\begin{array}{c}\text { Basal C-peptide } \\
(\mathrm{ng} / \mathrm{ml})\end{array}$ & $\begin{array}{c}\text { Stimulated C-peptide } \\
(\mathrm{ng} / \mathrm{ml})\end{array}$ & $\begin{array}{c}\text { Basal C-peptide } \\
(\mathrm{ng} / \mathrm{ml})\end{array}$ \\
\hline Female & 73 & $0.8 \pm 0.7$ & $1.5 \pm 1.2$ & $\begin{array}{c}\text { Stimulated C-peptide } \\
(\mathrm{ng} / \mathrm{ml})\end{array}$ \\
Male & 84 & $0.8 \pm 0.6$ & $1.6 \pm 1.3$ & $1.0 \pm 0.6$ \\
\hline
\end{tabular}

Values are means \pm S.D. Values for females and males are not statistically different.

Table 4 Comparison of male and female post-pubertal patients at the time of diagnosis and after 3 months of insulin therapy.

\begin{tabular}{|c|c|c|c|c|c|}
\hline \multirow[b]{2}{*}{ Sex } & \multirow[b]{2}{*}{ No. } & \multicolumn{2}{|c|}{ Diagnosis } & \multicolumn{2}{|c|}{3 months } \\
\hline & & $\begin{array}{l}\text { Basal C-peptide } \\
(\mathrm{ng} / \mathrm{ml})\end{array}$ & $\begin{array}{l}\text { Stimulated C-peptide } \\
(\mathrm{ng} / \mathrm{ml})\end{array}$ & $\begin{array}{l}\text { Basal C-peptide } \\
\text { (ng/ml }\end{array}$ & $\begin{array}{l}\text { Stimulated C-peptide } \\
(\mathrm{ng} / \mathrm{ml})\end{array}$ \\
\hline Female & 32 & $0.7 \pm 0.5^{\star \star}$ & $1.2 \pm 0.7$ & $1.0 \pm 0.5$ & $1.9 \pm 1.3$ \\
\hline Male & 63 & $1.1 \pm 0.6$ & $1.6 \pm 0.9$ & $1.2 \pm 0.6$ & $2.0 \pm 0.9$ \\
\hline
\end{tabular}

Values are means \pm S.D. ${ }^{* *} P=0.005$ compared with males.

smaller $(P=0.001)$ than males. Females also required a greater initial dose of insulin $(P=0.001)$, showed poorer glycaemic control (as measured by $\mathrm{HbA}_{1 \mathrm{c}}$; $P=0.023)$, a lower basal C-peptide $(P=0.021)$ and a marginally lower stimulated $C$-peptide $(P=0.075)$ at diagnosis.

After 3 months of therapy, both males and females showed a significant decline in insulin dose (both $P \leq 0.001)$ and in $\mathrm{HbA}_{1 \mathrm{c}}$ (both $P \leq 0.001$ ); however, only the insulin dose continued to show a significant difference between males and females, with females requiring more insulin to achieve good metabolic control $(P=0.001)$.

Puberty can influence the presentation of the disease, as documented in a previous paper (12). Although a detailed pubertal staging was not available, in order to control for the effect of puberty patients were categorized into three groups based on their age at the time of diagnosis: pre-pubertal (less than 9 years old), pubertal (9-18 years old) and post-pubertal (over 18 years of age). In view of what was mentioned above, the pubertal group might also have included also pre-pubertal and post-pubertal patients, although the number would be expected to be small. $\chi^{2}$ Analysis confirmed that there were no significant differences in the distribution of males and females across these three age categories. A separate independent-sample $t$-test comparing males and females was performed within each of these three age groups. Paired $t$-tests were used to test for change from diagnosis to 3 months separately for males and females. Tables 2-4 present the results of these analyses.

In the pre-pubertal group, there were no significant differences between males and females in basal C-peptide or stimulated C-peptide at the time of diagnosis and after 3 months of therapy (Table 2).

In the pubertal group, there were no significant differences between males and females in basal C-peptide or stimulated C-peptide (Table 3). The extent of residual $\beta$-cell function was similar in both groups at the time of diagnosis and after 3 months of treatment. Both females and males experienced, after 3 months of treatment, a significant increase in basal C-peptide $(P=0.002$ for males and females) and in stimulated C-peptide ( $P=0.046$ for females, $P=0.042$ for males).

In the post-pubertal group, there was a statistically significant difference in the amount of $\beta$-cell destruction between males and females at the time of diagnosis (Table 4). Females had lower concentrations of basal C-peptide $(P=0.005)$ and marginally lower concentrations of stimulated C-peptide that did not reach 
statistical significance $(P=0.094)$ compared with those in males. These sex differences disappeared after 3 months of treatment and there were no significant differences between males and females in either basal C-peptide $(P=0.153)$ or stimulated C-peptide $(P=$ 0.853) after therapy began. Females experienced an increase in basal C-peptide after 3 months of therapy $(P=0.026)$ and a marginal increase in stimulated C-peptide $(P=0.086)$. Males did not experience an increase in basal $\mathrm{C}$-peptide $(P=0.228)$, but did experience a significant increase in stimulated C-peptide $(P=0.038)$.

\section{Discussion}

Our data provide evidence that the process of $\beta$-cell destruction leading to type 1 diabetes is more extensive in females than in males. The number of patients studied and the fact that they were unselected cases reinforce our findings. Furthermore data are convincing as the major three variables of metabolic control (C-peptide, dose of insulin and $\mathrm{HbA}_{1 \mathrm{c}}$ ) are interrelated and more insulin is needed when C-peptide secretion is lower, which explains why, at the time of diagnosis of diabetes, female patients required more insulin to achieve good disease control. The variation in C-peptide between the sexes disappeared 3 months after the introduction of insulin. This also explains why, in established well-controlled type 1 diabetes, no metabolic differences are detectable between females and males, although females still need slightly more insulin than males 3 months after diagnosis.

In our study, the more extensive damage to $\beta$-cells observed in females was detected only when baseline, but not stimulated, C-peptide secretion was taken into account. It is not easy to explain such a finding; conceptually, baseline and stimulated C-peptide secretion may reflect different stages of $\beta$-cell destruction. Numerous studies have tried to clarify the significance of such secretion, which also may vary according to the stimulus used (e.g. glucagon or mixed meal). In our study, glucagon-stimulated C-peptide secretion was used and was similar between females and males at diagnosis.

Increased insulin resistance, which is known to be associated with puberty (13) and with a different age effect between females and males, would be able to explain our findings only partially. Because of the large variability in C-peptide values, differences between sexes in the pubertal groups were not apparent, although they might have been if the number of patients had been larger. The additional fact that, in the pre-pubertal age group (in which some females with early pubertal phenomena may have been included), there were no differences in C-peptide secretion between males and females rules out a major role for insulin resistance in explaining our findings. This concept is reinforced by the observation that post-pubertal females showed the greatest degree of $\beta$-cell destruction. However, we should also consider that females diagnosed in their early 20s tend to pay less attention than males to body weight loss associated with early disease. Often, losing weight is seen favourably by society, especially amongst females. Consequently, when these patients finally decide to go to their doctor, their metabolic decompensation is more advanced. Further research directed at clarifying the relationship between age, onset of puberty and time of diagnosis of diabetes is needed to enable a full understanding of the sex effect on $\beta$-cell destruction.

Our data indicate a greater degree of $\beta$-cell damage in females than in males with type 1 diabetes. A number of possibilities may be considered. One likely explanation of the more extensive destruction of $\beta$-cells in females could reside in a different genetic susceptibility between males and females. However, no differences in allele frequencies were reported between female and male diabetic patients from continental Italy with respect to HLA alleles or other genes linked to susceptibility (14). Differences in antibody prevalence between female and male patients have also not been reported $(15$, 16), but the possibility cannot be excluded that the T-cell response may progress faster and more aggressively in female diabetic patients. In the experimental model of the non-obese diabetic mouse, the prevalence of the disease is greater in females than males, the latter showing a similar degree of insulitis compared with female mice, but with less extensive destruction of $\beta$ cells (17).

In conclusion, we have shown in this study that adult females have a more extensive process of $\beta$-cell damage at diagnosis as assessed by C-peptide secretion. The implications of our findings may have relevance for early treatment of the disease and for trials aimed at preventing type 1 diabetes in susceptible individuals.

\section{Acknowledgements}

This work was supported by grants from the University of Rome, Campus Biomedico and the International Centre for the Study of Diabetes (CISD Rome, Italy).

The IMDIAB Group comprises: P Pozzilli, S Manfrini, G Coppolino, C A Mesturino, N Visalli, M Delli Castelli, P Patera, M C Matteoli, A Crinò, S Corbi, S Spera, C Suraci, G Multari, N Sulli, M Cervoni, G De Mattia, M R Cassone Faldetta, M L Manca Bitti, A Cantagallo, G Marietti, S Piccinini, F Ferrazzoli, C Bizzarri, D Pitocco and G Ghirlanda.

\section{References}

1 Atkinson M \& Mc Laren NK. The pathogenesis of insulin-dependent diabetes mellitus. New England Journal of Medicine 1994 331 1428-1436.

2 Pinkey JH, Bingley PJ \& Sawtell PA. The Barts-Oxford Study Group. Presentation and progress of childhood diabetes mellitus: 
a prospective population based study. Diabetologia 199437 $70-73$.

3 Pozzilli P, Visalli N \& Buzzetti R. IMDIAB group. Metabolic and immune parameters at clinical onset of insulin-dependent diabetes: a population based study. Metabolism $1998 \quad \mathbf{4 7}$ $1205-1210$

4 Green A, Gale EAM \& Patterson CC. Incidence of childhood insulin dependent diabetes mellitus: the EURODIAB ACE Study. Lancet $1992339905-909$.

5 Visalli N, Sebastiani L, Adorisio E, Cassone Faldetta MR, Buzzetti $\mathrm{R}$, Pozzilli P et al. Sex differences in the incidence of type 1 diabetes in two Italian regions: Lazio and Sardinia. Diabetologia 1999 42A 85.

6 Pozzilli P, Visalli N, Buzzetti R, Fava D, Signore A, Cavallo MG et al. Double blind trial of nicotinamide in recent onset insulin dependent diabetes mellitus. Diabetologia 199538 848-852.

7 Pozzilli P, Visalli N, Signore A, Cavallo MG, Baroni MG, Buzzetti R et al. Vitamin $\mathrm{E}$ and nicotinamide have similar effects in maintaining residual beta cell function in recent onset insulin dependent diabetes mellitus (the IMDIAB IV Study). European Journal of Endocrinology $1997137234-239$.

8 Snorgaard O, Larsen LH \& Binder C. Homogeneity in pattern of decline of beta cell function in type 1 diabetes. Diabetes Care $1992151009-1015$.

9 Komulainen J, Akerblom HK, Lounamaa R \& Knip M. Prepubertal girls with insulin-depenent diabetes mellitus have higher exogenous insulin requirement than boys. Childhood Diabetes in Finland Study Group. European Journal of Pediatrics $19989708-711$.

10 Sebastiani L, Visalli N \& Adorisio E. A five year (1989-1993) prospective study of the incidence of insulin dependent diabetes in
Rome and the Lazio region in the age group 0-14 years. Diabetes Care $19961970-73$

11 Shah SC, Malone JI \& Simpson NE. A randomized trial of intensive insullin therapy in newly diagnosed insulin-dependent diabetes. New England Journal of Medicine $19893 \mathbf{3 0} 550-555$.

12 Amiel SA, Caprio S \& Sherwin RS. Insulin resistance of puberty: a defect restricted to peripherial metabolism. Journal of Clinical Endocrinology and Metabolism 199172 277-282.

13 Levy-Marchal C, Papoz L \& de Beaufort C. Clinical and laboratory features of Type 1 diabetic children at time of diagnosis. Diabetic Medicine 19929 279-284.

14 Buzzetti R, Nisticò L, Osborn JF, Giovannini C, Chersi A \& Sorrentino R. HLA-DQA1 and DQB1 gene polymorphism in type 1 diabetic patients from central Italy and their use for risk prediction. Diabetes 199342 1173-1178.

15 Genovese S, Bonfanti R, Bazzicalupi E, Lampasona V, Benazzi E, Bosi E et al. Association of IA-2 autoantibodies with HLA-DR4 aplotypes in type 1 diabetes. Diabetologia $1996391223-1226$.

16 Bonfanti R, Bazzigaluppi E, Calori G, Riva MC, Viscardi M, Bognetti $\mathrm{E}$ et al. Parameters associated with residual insulin secretion during the first year of disease in children and adolescents with type 1 diabetes mellitus. Diabetic Medicine 199815 844-850.

17 Hawkins T, Gala RR \& Dunbar JC. The effect of neonatal sex hormone manipulation on the incidence of diabetes in nonobese diabetic mice. Proceedings of the Society for Experimental Biology and Medicine 1993202 201-205.

Received 2 August 2001

Accepted 31 August 2001 